\title{
Chemical and Pathogen Impacts on Human Health near Aquaculture Areas in West Godavari District of Andhra Pradesh, India
}

\author{
D. Nageswara Rao*, T. Bhaskara Rao*† and P.V.S. Machiraju** \\ *Department of Chemistry, Koneru Lakshmaiah Education Foundation, Guntur-522502, A.P., India \\ **Department of Chemistry, Pragati Engineering College (A), Surampalem-533437, A.P., India \\ †Corresponding author: T. Bhaskara Rao: tbhaskararao208@gmail.com
}

Nat. Env. \& Poll. Tech.

Website: www.neptjournal.com

Received: 05-10-2020

Revised: 25-11-2020

Accepted: 08-12-2020

\section{Key Words:}

Groundwater

Aquaculture

Microbial characterization

Water quality

Toxicity

\begin{abstract}
Water is essential for all living organisms in the universe. Chemicals can cause contamination in groundwater near aquacultural activity areas. Keeping in view the hectic aquacultural activity in surrounding locations of Akividu town in West Godavari District of AP, India, it is proposed to assess the chemical and microbial contamination of waters to suggest remedial measures to protect the quality of water for safeguarding the health of the public residing in the nearby habitations who consume these waters for drinking purposes. 16 Groundwater samples were collected and analyzed for assessing the physicochemical parameters viz., pH, Electrical conductivity (EC), Total Dissolved solids (TDS), Total hardness (TH), Total Alkalinity (TA), $\mathrm{Na}^{+}, \mathrm{K}^{+}$, Calcium, Magnesium, Chloride, Sulphate, Nitrate and Phosphate, Irrigation parameters like \%Na, SAR, KR RSC, and microbial analysis. The study results revealed that the samples were contaminated chemically and also with pathogenic bacteria like Pseudomonas, Citrobacter freundii and Escherichia coli which can cause water-borne diseases. Further, a health survey was carried out to verify the adverse effects to be caused by the chemical and microbial contamination of water on people's health. The health survey results indicated the sufferings of the people who consume this water for drinking and domestic purposes. The waters are to be treated accordingly to control the chemical and bacterial contamination by using the available treatment methodologies before considering them for drinking purposes.
\end{abstract}

\section{INTRODUCTION}

Groundwater recharge is being done by various water bodies. Physico-chemical characteristics of an aquatic body not only reflect the type and diversity of aquatic biota but also the water quality and its contamination (Mir et al. 2004). Research studies (Raveen et al. 2008) revealed the necessity for the restoration of degrading freshwater bodies to ensure the sustainability of a healthy ecosystem. The environmental impact of aquaculture in the country came to the limelight for the first time with the reports of NEERI (1995). Intensive aquaculture requires huge quantities of freshwater from groundwater sources (Ramesh et al. 2008). Using significant volumes of groundwater to create the required salinity levels of brackish water for aquaculture activity can cause salinization of groundwater aquifers (Dahdouh-Guebas et al. 2006). The research studies (Alagarswamy 1995) revealed that shrimp farming and other farming systems can lead to pollution and result in adverse impacts on the environment. Higher quantities of nitrogen and phosphorus in feeds during aquaculture can also cause an increase in nutrient concentration in waters. The excess nutrient concentrations may deteriorate the water in the aquatic environment
(Falconer et al. 2018). The research studies indicated that the values of SAR and RSC indicate $97 \%$ of the waters and their suitability for domestic, irrigation, and industrial purposes (Nagaraju \& Papanna 2009).

The bacteria and pathogenic organisms present in drinking water can cause health hazards like dysentery, cholera, fevers, hepatitis, intestinal disorders, etc. Presence of coli form in water is an indicator of harmful bacteria but all the bacteria are not harmful (Massoud et al. 2010, Joao 2010). Microbial pathogenic bacteria in water can cause diarrhoeal diseases nearly up to $82 \%$ of diseases (WHO 2010). Several microbial communities that survive in waters start multiplying and depreciate the water quality (Ikonen et al. 2017). Pathogen contamination of waters is a significant health risk and also a threat to the water supplies essential for living and other recreational activities. Low levels of contact with contaminated water are significant and can cause an outbreak of gastroenteritis (Madoux-Humey et al. 2016, Boehm \& Sassoubre 2014). Though coli forms do not cause serious illness, they act as an indicator for the presence of more (Ibrahim et al. 2014). Approximately 3.4 million people particularly children die from water-borne diseases (WHO 
2014). Various studies (Arnone \& Walling 2007) revealed that gastrointestinal problems can be caused by different microbes and germs present in water bodies which indicate the symptoms like diarrhea, nausea, vomiting, fever, and abdominal pains (Arnone \& Walling 2007).

Keeping in view of hectic aquaculture activity and the release of backwaters due to its activity and the seepage of these waters into groundwater sources, it is proposed to carry out the characterization of groundwater near aquaculture activity areas to evaluate the chemical and pathogenic impacts through groundwater sources on the public health through their utility for drinking and domestic purposes and to suggest remedial measures to protect the health of the public.

\section{MATERIALS AND METHODS}

The sampling locations are identified near aquacultural activity areas around Akividu of West Godavari District of Andhra Pradesh, India. The samples were collected in polythene containers and preserved for analysis as per the standard procedures (Ramteke \& Moghe 1988, APHA 1992). The details of sample code, sampling locations along with their coordinates are presented in Table 1 and the study area map is presented in Fig. 1.

Table 1: Sample code, location and coordinates.

\begin{tabular}{|lll|}
\hline Sample Code & Sample Location & GPS Co-ordinates \\
\cline { 3 - 3 } & & Latitude \\
\hline AE-1 & Cherukuvada main road, near Hossanna mandir & 16.58411 \\
AE-2 & Cherukuvada main road, near Anjanayaswami temple & 16.58390 \\
AE-3 & Akivedu, near Vinayaka Industry & 16.58473 \\
AE-4 & Cherukuvad (undi road), near Church & 16.58644 \\
AW-1 & Manchineeti Cheruvugattu & 16.57885 \\
AW-2 & Kaikaluru road, near SV Godowns & 16.57785 \\
AW-3 & Near SV Godowns & 16.57880 \\
AW-4 & Near SV Godowns & 16.57856 \\
AN-1 & Near Alapadu main road & 16.57494 \\
AN-2 & Kolletikota, near Alapadu turning & 16.58087 \\
AN-3 & Kalletikota road, near Alapadu Panchayathi Cheruvu & 16.58207 \\
AN-4 & Kolletikota road, near Hanuman Temple & 16.59303 \\
AS-1 & Main road, near Telephone Exchange & 16.58241 \\
AS-2 & Near Telephone Exchange & 16.58257 \\
AS-3 & Argumuru Garuvu & 16.58253 \\
AS-4 & Main road, near Anjanaya temple & 16.58435 \\
\hline
\end{tabular}

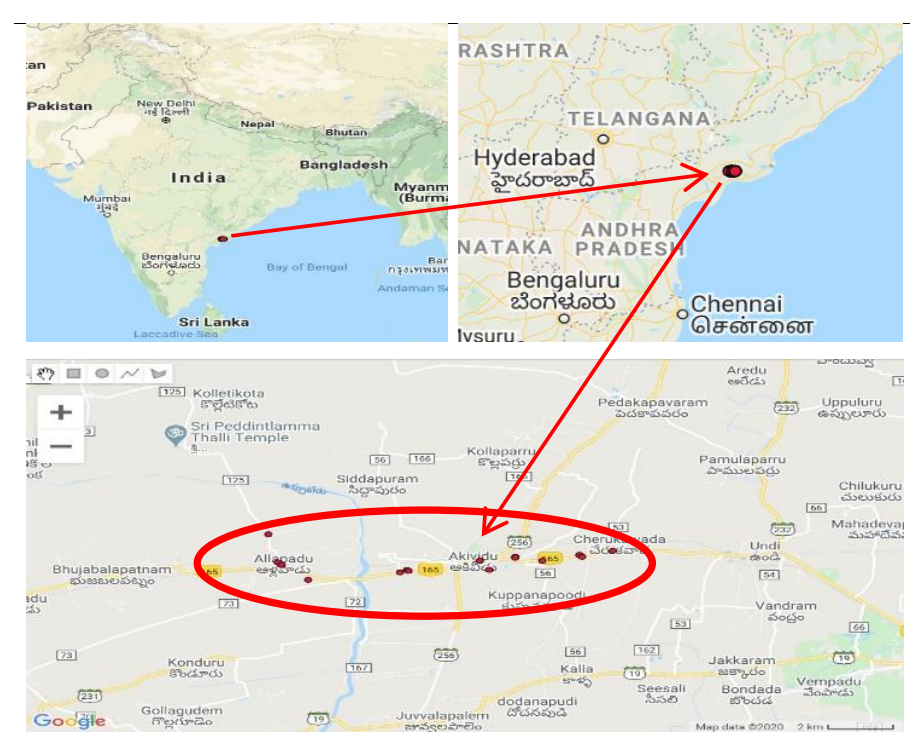

Fig. 1: Study area map (Google map). 


\section{Physicochemical Parameters}

The waters were characterized for physicochemical parameters viz., pH, Electrical conductivity (EC), Total Dissolved solids (TDS), Total hardness (TH), Total Alkalinity (TA), $\mathrm{Na}+, \mathrm{K}+$, Calcium and Magnesium, Chloride, Sulphate, Nitrate, and Phosphate. $\mathrm{pH}$ is determined by $\mathrm{pH}$ Meter (Model-PCS Tester35, Eutech) and conductivity measured by portable EC sensor (Electrode based). TDS is determined by TDS Sensor (Electrode based). Total Hardness, Total Alkalinity, and Chloride are estimated by titrimetry. Sulfate and Phosphate are estimated by spectrophotometer (Model-106, Systronics), $\mathrm{Na}^{+}$and $\mathrm{K}^{+}$by Flame photometer (Model-128, Systronics), and Nitrate by using Ion-selective electrode (Model-HI 3222 pH/ORP/ISE Meter, HANNA). The irrigation parametric levels, Percent Sodium (\%Na), Sodium Adsorption Ratio (SAR), Residual Sodium Carbonate (RSC), Kelly's Ratio (KR), Magnesium Hazard (MH) are determined by using equations.

Percent Sodium $(\% \mathrm{Na})=\frac{\mathrm{Na}^{+} \mathrm{X} 100}{\mathrm{Ca}^{2+}+\mathrm{Mg}^{2+}+\mathrm{Na}^{+}+\mathrm{K}^{+}}(\mathrm{meq} / \mathrm{l})$

Sodium Adsorption Ratio (SAR) $=\frac{\mathrm{Na}^{+}}{\sqrt{\frac{\mathrm{Ca}^{2+}+M g^{2+}}{2}}}(\mathrm{meq} / \mathrm{I})$
Residual Sodium Carbonate $(\mathrm{RSC})=\left(\mathrm{CO}_{3}{ }^{2-}+\mathrm{HCO}_{3}{ }^{-}\right)$ $-\left(\mathrm{Ca}^{2+}+\mathrm{Mg}^{2+}\right)(\mathrm{meq} / \mathrm{L})$

$$
\text { Kelly Ratio }(\mathrm{KR})=\frac{\mathrm{Na}^{+}}{\mathrm{Ca}^{2+}+\mathrm{Mg}^{2+}}
$$

Magnesium Hazard $(\mathrm{MH})=\frac{\mathrm{Mg}^{2+}}{\mathrm{Ca}^{2+}+\mathrm{Mg}^{2+}} \mathrm{X} 100$

\section{Microbial Characterization}

MPN Count: MPN count in water samples was done by the standard MPN index method.

Identification of Bacteria: The identification of bacterial species was carried out by the cultural characteristics using staining reactions to identify the shape and the color of the microorganisms and biochemical characterization which include IMViC (Indole production test, Methyl red test, Voges Proskauer test, Citrate utilization) tests (Obiri-Danso \& Jones 1999a, 1999b, Sohan \& Iqbal 2012).

\section{RESULTS AND DISCUSSION}

The values of physicochemical characteristics of the groundwater near aquacultural areas are presented in Tables 2, 3 and 4 and values for irrigational param-

Table 2: Physicochemical characteristics of groundwater near aquacultural areas.

\begin{tabular}{|c|c|c|c|c|c|c|c|c|c|c|c|c|c|c|}
\hline \multirow[t]{3}{*}{$\begin{array}{l}\text { Sample } \\
\text { Code }\end{array}$} & \multicolumn{2}{|c|}{ Temp $\left({ }^{\circ} \mathrm{C}\right)$} & \multicolumn{2}{|l|}{$\mathrm{pH}$} & \multicolumn{2}{|c|}{$\begin{array}{l}\mathrm{EC} \\
(\mu \mathrm{mhos} / \mathrm{cm})\end{array}$} & \multicolumn{2}{|c|}{$\begin{array}{l}\text { TDS } \\
(\mathrm{mg} / \mathrm{L})\end{array}$} & \multicolumn{2}{|c|}{$\begin{array}{l}\text { Salinity } \\
\text { (mg/L) }\end{array}$} & \multicolumn{2}{|c|}{$\begin{array}{l}\mathrm{TH} \\
(\mathrm{mg} / \mathrm{L})\end{array}$} & \multicolumn{2}{|c|}{$\begin{array}{l}\mathrm{TA} \\
(\mathrm{mg} / \mathrm{L})\end{array}$} \\
\hline & \multicolumn{2}{|c|}{ Monsoon } & \multicolumn{2}{|c|}{ Monsoon } & \multicolumn{2}{|c|}{ Monsoon } & \multicolumn{2}{|c|}{ Monsoon } & \multicolumn{2}{|c|}{ Monsoon } & \multicolumn{2}{|c|}{ Monsoon } & \multicolumn{2}{|c|}{ Monsoon } \\
\hline & Pre & Post & Pre & Post & Pre & Post & Pre & Post & Pre & Post & Pre & Post & Pre & Post \\
\hline AE-1 & 29.0 & 30.4 & 8.43 & 8.15 & 3920 & 1575 & 2770 & 1120 & 2150 & 826 & 350 & 500 & 70 & 1300 \\
\hline AE-2 & 28.9 & 30.5 & 8.10 & 6.93 & 8630 & 1230 & 6080 & 870 & 4960 & 640 & 1700 & 2150 & 130 & 1700 \\
\hline AE-3 & 29.0 & 30.4 & 7.60 & 7.57 & 3730 & 1270 & 2640 & 917 & 2040 & 977 & 780 & 1150 & 80 & 1070 \\
\hline AE-4 & 28.9 & 30.4 & 8.45 & 7.84 & 2630 & 1510 & 1850 & 1070 & 1400 & 795 & 430 & 450 & 100 & 1660 \\
\hline AW-1 & 29.1 & 30.5 & 8.08 & 8.14 & 3100 & 927 & 2190 & 663 & 1680 & 481 & 630 & 300 & 100 & 1420 \\
\hline AW-2 & 29.0 & 30.3 & 8.75 & 7.94 & 5720 & 670 & 4040 & 476 & 3210 & 3850 & 580 & 2800 & 90 & 1850 \\
\hline AW-3 & 29.0 & 30.5 & 8.83 & 8.18 & 3100 & 4320 & 2190 & 3080 & 1680 & 2410 & 240 & 700 & 80 & 2030 \\
\hline AW-4 & 29.1 & 30.5 & 7.84 & 8.11 & 15000 & 1745 & 10590 & 1250 & 9030 & 932 & 2300 & 700 & 100 & 1570 \\
\hline $\mathrm{AN}-1$ & 29.1 & 30.3 & 7.77 & 8.19 & 14710 & 4320 & 10385 & 3080 & 8770 & 2420 & 2800 & 900 & 70 & 1700 \\
\hline AN-2 & 29.1 & 30.4 & 8.33 & 8.92 & 10100 & 5250 & 7140 & 3740 & 5910 & 2970 & 1060 & 600 & 100 & 1830 \\
\hline AN-3 & 29.1 & 30.4 & 8.03 & 8.67 & 7370 & 3680 & 5190 & 2630 & 4200 & 2020 & 820 & 1000 & 90 & 890 \\
\hline AN-4 & 29.1 & 30.4 & 7.73 & 8.12 & 6900 & 3680 & 4860 & 2660 & 3900 & 2080 & 860 & 1700 & 50 & 1650 \\
\hline AS-1 & 29.0 & 30.5 & 7.68 & 8.15 & 1659 & 1320 & 1180 & 937 & 873 & 690 & 240 & 300 & 50 & 1130 \\
\hline AS-2 & 29.1 & 30.5 & 8.21 & 7.25 & 2060 & 736 & 1460 & 524 & 1110 & 379 & 370 & 100 & 60 & 280 \\
\hline AS-3 & 29.0 & 30.4 & 8.14 & 7.20 & 2370 & 1400 & 1670 & 1010 & 1260 & 742 & 470 & 900 & 60 & 1250 \\
\hline AS-4 & 29.1 & 30.4 & 8.11 & 7.49 & 3070 & 1600 & 2170 & 1140 & 1660 & 852 & 1110 & 700 & 50 & 350 \\
\hline BIS value & - & & $6.5-8$ & & - & & 500 & & - & & 200 & & 200 & \\
\hline
\end{tabular}


Table 3: Physicochemical characteristics of groundwater near aquacultural areas.

\begin{tabular}{|c|c|c|c|c|c|c|c|c|}
\hline \multirow[t]{3}{*}{ Sample Code } & \multicolumn{2}{|c|}{$\mathrm{Cl}^{-}(\mathrm{mg} / \mathrm{L})$} & \multicolumn{2}{|c|}{$\mathrm{SO}_{4}{ }^{2-}(\mathrm{mg} / \mathrm{L})$} & \multicolumn{2}{|c|}{$\mathrm{PO}_{4}{ }^{3-}(\mathrm{mg} / \mathrm{L})$} & \multicolumn{2}{|c|}{$\mathrm{NO}_{3}{ }^{-}(\mathrm{mg} / \mathrm{L})$} \\
\hline & \multicolumn{2}{|l|}{ Monsoon } & \multicolumn{2}{|c|}{ Monsoon } & \multicolumn{2}{|c|}{ Monsoon } & \multicolumn{2}{|c|}{ Monsoon } \\
\hline & Pre & Post & Pre & Post & Pre & Post & Pre & Post \\
\hline AE-1 & 1155.67 & 744.45 & 73.57 & 133.57 & 0.61 & 1.13 & 29.5 & 17.4 \\
\hline AE-2 & 2431.87 & 2906.9 & 334.57 & 270.71 & 2.33 & 1.78 & 36.4 & 30.5 \\
\hline AE-3 & 765.72 & 744.45 & 244.29 & 1742.80 & 0.11 & 0.62 & 109.0 & 13.4 \\
\hline AE-4 & 446.67 & 744.45 & 178.00 & 128.71 & 0.13 & 0.53 & 54.2 & 43.7 \\
\hline AW-1 & 517.57 & 567.2 & 225.29 & 56.85 & 3.19 & 1.07 & 19.3 & 18.4 \\
\hline AW-2 & 1474.72 & 15030.8 & 307.14 & 3.54 & 0.00 & 1.29 & 95.3 & 69.7 \\
\hline AW-3 & 588.47 & 1807.95 & 235.71 & 308.71 & 0.64 & 4.73 & 112.0 & 70.1 \\
\hline AW-4 & 5835.07 & 921.7 & 348.43 & 170.00 & 3.86 & 0.7 & 153.0 & 19.2 \\
\hline AN-1 & 6083.22 & 2197.9 & 334.57 & 114.14 & 3.29 & 0.43 & 66.9 & 36.3 \\
\hline $\mathrm{AN}-2$ & 3708.07 & 2552.4 & 184.86 & 307.57 & 0.14 & 1.93 & 60.3 & 337 \\
\hline AN-3 & 2502.77 & 2197.9 & 135.14 & 234.85 & 1.01 & 3.89 & 47.6 & 37.9 \\
\hline $\mathrm{AN}-4$ & 2396.42 & 2906.9 & 257.00 & 230.85 & 1.63 & 1.4 & 50.2 & 71.7 \\
\hline AS-1 & 233.97 & 212.7 & 118.57 & 101.42 & 0.50 & 1.2 & 194.0 & 48.4 \\
\hline AS-2 & 304.87 & 567.2 & 170.57 & 60.00 & 0.47 & 3.87 & 191.0 & 9.65 \\
\hline AS-3 & 588.47 & 921.7 & 128.71 & 219.71 & 2.08 & 1.01 & 18.9 & 19.9 \\
\hline AS-4 & 907.52 & 1276.2 & 74.14 & 145.00 & 3.39 & 0.14 & 29.3 & 17.5 \\
\hline BIS value & 250 & & 200 & & - & & 45 & \\
\hline
\end{tabular}

Table 4: Physicochemical characteristics of groundwater near aquacultural areas.

\begin{tabular}{|c|c|c|c|c|c|c|c|c|}
\hline \multirow[t]{3}{*}{ Sample Code } & \multicolumn{2}{|c|}{$\mathrm{Ca}^{2+}(\mathrm{mg} / \mathrm{L})$} & \multicolumn{2}{|c|}{$\left.\mathrm{Mg}^{2+}(\mathrm{mg} / \mathrm{L})\right)$} & \multicolumn{2}{|c|}{$\mathrm{Na}^{+}(\mathrm{mg} / \mathrm{L})$} & \multicolumn{2}{|c|}{$\mathrm{K}^{+}(\mathrm{mg} / \mathrm{L})$} \\
\hline & \multicolumn{2}{|c|}{ Monsoon } & \multicolumn{2}{|c|}{ Monsoon } & \multicolumn{2}{|c|}{ Monsoon } & \multicolumn{2}{|c|}{ Monsoon } \\
\hline & Pre & Post & Pre & Post & Pre & Post & Pre & Post \\
\hline AE-1 & 120 & 80 & 12.2 & 73.2 & 1936.2 & 293.8 & 59.4 & 10.6 \\
\hline AE-2 & 500 & 160 & 109.8 & 427 & 828.0 & 607.6 & 23.6 & 6.4 \\
\hline AE-3 & 200 & 120 & 68.32 & 207.4 & 1722.8 & 400.0 & 605.0 & 13.5 \\
\hline AE-4 & 120 & 80 & 31.72 & 61 & 497.6 & 228.0 & 186.4 & 93.7 \\
\hline AW-1 & 220 & 80 & 19.52 & 24.4 & 678.2 & 89.3 & 332.7 & 24.2 \\
\hline AW-2 & 180 & 160 & 31.72 & 585.6 & 2296.8 & 1962.2 & 18.4 & 29.2 \\
\hline AW-3 & 40 & 120 & 34.16 & 97.6 & 1137.3 & 872.7 & 16.5 & 25.5 \\
\hline AW-4 & 760 & 120 & 97.6 & 97.6 & 3738.0 & 384.6 & 114.8 & 8.5 \\
\hline AN-1 & 780 & 160 & 207.4 & 122 & 3576.8 & 925.1 & 109.6 & 14.5 \\
\hline $\mathrm{AN}-2$ & 400 & 80 & 14.64 & 97.6 & 2378.2 & 916.5 & 70.8 & 293.9 \\
\hline $\mathrm{AN}-3$ & 240 & 120 & 53.68 & 170.8 & 1669.0 & 807.8 & 25.4 & 66.1 \\
\hline AN-4 & 260 & 80 & 51.24 & 366 & 1662.4 & 901.1 & 111.2 & 26.3 \\
\hline AS-1 & 80 & 80 & 9.76 & 24.4 & 238.8 & 122.6 & 255.2 & 151 \\
\hline AS-2 & 120 & 40 & 17.08 & BDL & 276.0 & 77.9 & 401.8 & 17.1 \\
\hline AS-3 & 100 & 120 & 53.68 & 146.4 & 564.6 & 235.5 & 17.6 & 9.8 \\
\hline AS-4 & 220 & 80 & 136.64 & 122 & 540.2 & 326.9 & 26.0 & 8.5 \\
\hline BIS Value & 75 & & 30 & & - & & - & \\
\hline
\end{tabular}


Table 5: Irrigation parametric values of groundwater near aquacultural areas.

\begin{tabular}{|c|c|c|c|c|c|c|c|c|c|c|}
\hline \multirow[t]{3}{*}{ Sample Code } & \multicolumn{2}{|c|}{$\% \mathrm{Na}(\mathrm{me} / \mathrm{L})$} & \multicolumn{2}{|c|}{ SAR (me/L) } & \multicolumn{2}{|c|}{ RSC (me/L) } & \multicolumn{2}{|c|}{ Kelly's Ratio } & \multicolumn{2}{|l|}{$\mathrm{MH}$} \\
\hline & \multicolumn{2}{|c|}{ Monsoon } & \multicolumn{2}{|c|}{ Monsoon } & \multicolumn{2}{|c|}{ Monsoon } & \multicolumn{2}{|c|}{ Monsoon } & \multicolumn{2}{|c|}{ Monsoon } \\
\hline & Pre & Post & Pre & Post & Pre & Post & Pre & Post & Pre & Post \\
\hline AE-1 & 90.8 & 55.8 & 45.1 & 5.8 & BDL & 16.1 & 12.1 & 1.3 & 14.0 & 59.4 \\
\hline AE-2 & 51.1 & 38.4 & 8.8 & 5.8 & BDL & BDL & 1.1 & 0.6 & 26.0 & 81.0 \\
\hline AE-3 & 70.8 & 43.1 & 26.9 & 5.2 & BDL & BDL & 4.8 & 0.8 & 35.3 & 73.4 \\
\hline AE-4 & 61.9 & 46.8 & 10.5 & 4.7 & BDL & 24.3 & 2.5 & 1.1 & 29.7 & 55.0 \\
\hline AW-1 & 58.3 & 37.1 & 11.8 & 2.3 & BDL & 22.4 & 2.3 & 0.7 & 12.4 & 32.8 \\
\hline AW-2 & 89.3 & 60.5 & 41.6 & 16.3 & BDL & BDL & 8.7 & 1.6 & 22.0 & 85.4 \\
\hline AW-3 & 90.6 & 72.4 & 32.1 & 14.4 & BDL & 26.8 & 10.4 & 2.7 & 57.7 & 56.5 \\
\hline AW-4 & 76.9 & 54.4 & 34.0 & 6.4 & BDL & 17.6 & 3.5 & 1.2 & 17.0 & 56.5 \\
\hline $\mathrm{AN}-1$ & 72.7 & 68.9 & 29.5 & 13.5 & $\mathrm{BDL}$ & 16.2 & 2.8 & 2.3 & 29.8 & 55.0 \\
\hline $\mathrm{AN}-2$ & 81.8 & 67.3 & 31.8 & 16.4 & BDL & 24.2 & 4.9 & 3.4 & 5.5 & 66.1 \\
\hline AN-3 & 81.1 & 62.2 & 25.4 & 11.2 & BDL & $\mathrm{BDL}$ & 4.5 & 1.8 & 26.4 & 69.5 \\
\hline AN-4 & 78.4 & 53.6 & 24.7 & 9.6 & BDL & BDL & 4.2 & 1.2 & 24.0 & 88.0 \\
\hline AS-1 & 47.9 & 35.2 & 6.7 & 3.1 & BDL & 16.6 & 2.2 & 0.9 & 16.3 & 32.8 \\
\hline AS-2 & 40.5 & 58.2 & 6.3 & 3.4 & BDL & 3.6 & 1.6 & 1.7 & 18.5 & 0.0 \\
\hline AS-3 & 71.6 & 36.3 & 11.4 & 3.4 & BDL & 7.3 & 2.6 & 0.6 & 46.2 & 66.1 \\
\hline $\mathrm{AS}-4$ & 51.0 & 50.4 & 7.1 & 5.4 & BDL & BDL & 1.1 & 1.0 & 49.8 & 70.9 \\
\hline Standard Value & 60 & & 26 & & 1.0 & & 1.0 & & 50 & \\
\hline
\end{tabular}

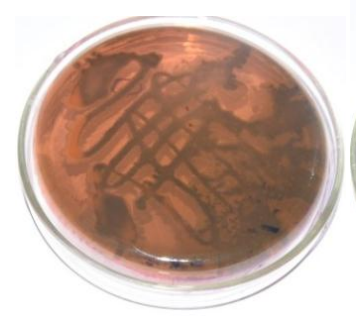

AE-1: Pseudomonas

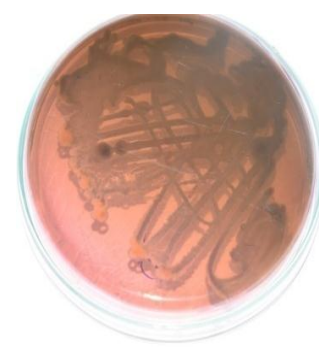

AN-1: Pseudomonas
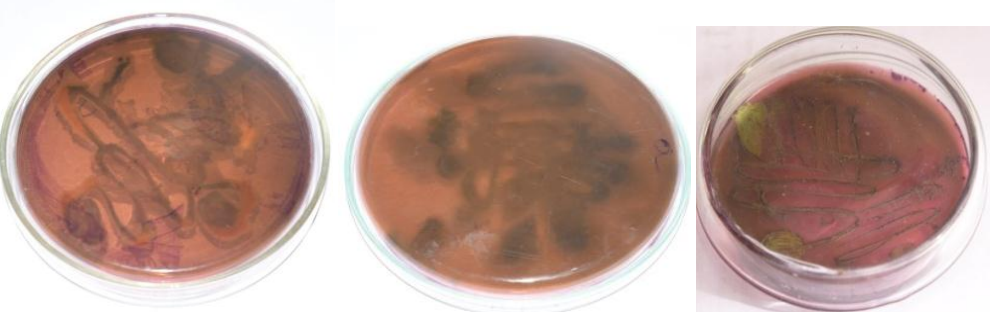

AE-2: Citrobacter

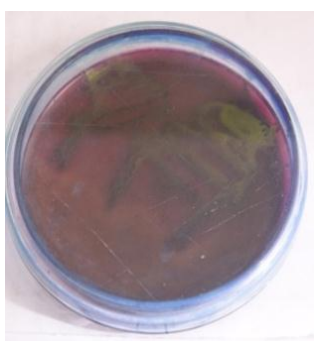

AN-2: E. coli

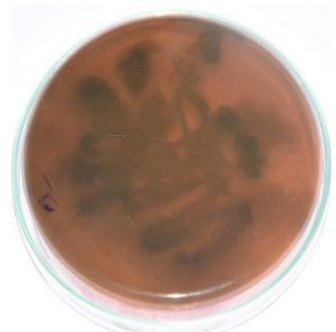

AS-1: Citrobacter

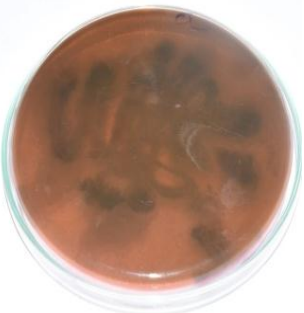

AS-2: Citrobacter

Fig. 2: Photographs of the identified microbial species. 


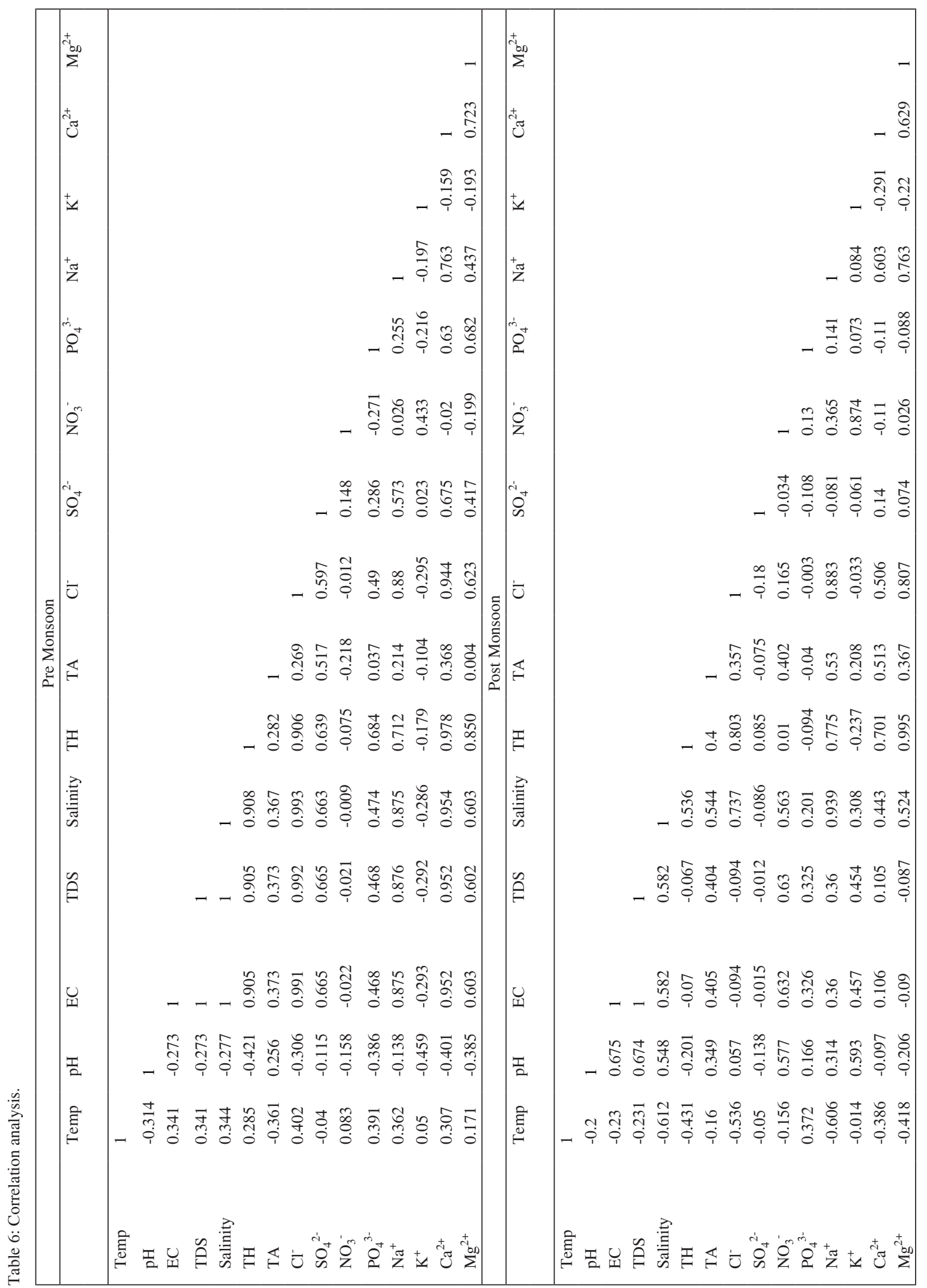


eters in Table 5. The details of MPN count and the identified bacterial species are presented in Table 7 . The Photographs of the identified microbial species in waters are presented in Fig. 2.

The MPN count observed in waters is presented in Fig. 3. A health survey was carried out in the study area and the age details of the public and diseases experienced by them are summarized in Table 8.

The percentage of diseases experienced by the people in the study area is represented in Fig. 4.
Physicochemical characteristics: The analytical results of physicochemical parameters are presented in Tables 2, 3 and 4 along with the BIS standard values which reveal that the temperature during the collection of samples ranges from $28.9^{\circ} \mathrm{C}$ to $29.1^{\circ} \mathrm{C}$ and the $\mathrm{pH}$ of waters during pre-monsoon and post-monsoon seasons range from 7.60-8.83 and 6.938.92 respectively. The values indicate the slight alkaline nature of waters. Microorganisms depend on water for their growth depending on the water activity gradient. All microorganisms prefer $\mathrm{pH} 7$ (neutral) for their optimum growth but they can grow more in acidic $\mathrm{pH}$ values. They

Table 7: Details of MPN count and identified bacterial species in waters.

\begin{tabular}{|c|c|c|c|c|c|c|c|c|c|}
\hline \multirow{2}{*}{$\begin{array}{l}\text { Sample } \\
\text { Code }\end{array}$} & \multirow{2}{*}{$\begin{array}{l}\text { MPN } \\
\text { Index }\end{array}$} & \multirow{2}{*}{$\begin{array}{l}\text { No. of bacterial } \\
\text { colonies on EMB }\end{array}$} & \multirow{2}{*}{$\begin{array}{l}\text { Bacterial colony } \\
\text { Morphology on EMB }\end{array}$} & \multirow{2}{*}{$\begin{array}{l}\text { Gram's } \\
\text { Nature }\end{array}$} & \multicolumn{4}{|c|}{$*(\mathrm{IMViC}$ tests $)$} & \multirow[t]{2}{*}{ Bacteria Species } \\
\hline & & & & & I & MR & $\mathrm{VP}$ & $\mathrm{C}$ & \\
\hline AE-1 & 02 & 02 & Colourless & -ve & - & - & - & - & Pseudomonas \\
\hline AE-2 & 31 & 02 & Colourless & -ve & + & + & -- & + & Citrobacter freundii \\
\hline AW-1 & 22 & 01 & Colourless & -ve & + & + & - & + & Citrobacter freundii \\
\hline AW-2 & 02 & 01 & Green Metallic Sheen & -ve & + & + & - & - & E. coli \\
\hline $\mathrm{AN}-1$ & 02 & 01 & Colourless & -ve & - & - & - & - & Pseudomonas \\
\hline $\mathrm{AN}-2$ & 02 & 02 & Green Metallicsheen & -ve & + & + & - & - & E. coli \\
\hline AS-1 & 01 & 01 & Colourless & -ve & + & + & - & + & Citrobacter freundii \\
\hline AS-2 & 01 & 01 & Colourless & -ve & + & + & - & + & Citrobacter freundii \\
\hline
\end{tabular}

*I = Indole, MR=Methyl red, $\mathrm{VP}=$ VogesProskauer, $\mathrm{C}=\mathrm{Citarte}$

Table 8: Details of people's age and disease experienced.

\begin{tabular}{|c|c|c|c|c|c|c|}
\hline \multirow[t]{2}{*}{ Age in Yrs } & \multicolumn{5}{|c|}{ Diseases Experienced } & \multirow[t]{2}{*}{ Total } \\
\hline & Fever & Gastro Intestinal troubles & Joint pains & Typhoid & Skin Allergy & \\
\hline $1-10$ & 12 & 0 & 1 & 0 & 5 & 18 \\
\hline $11-20$ & 0 & 0 & 0 & 0 & 1 & 1 \\
\hline $21-30$ & 2 & 3 & 3 & 0 & 1 & 9 \\
\hline $31-40$ & 3 & 5 & 1 & 1 & 5 & 15 \\
\hline $41-50$ & 2 & 6 & 1 & 0 & 1 & 10 \\
\hline $51-60$ & 0 & 1 & 0 & 0 & 2 & 3 \\
\hline Above 60 & 0 & 1 & 1 & 0 & 0 & 2 \\
\hline Total & 19 & 16 & 7 & 1 & 15 & 58 \\
\hline
\end{tabular}

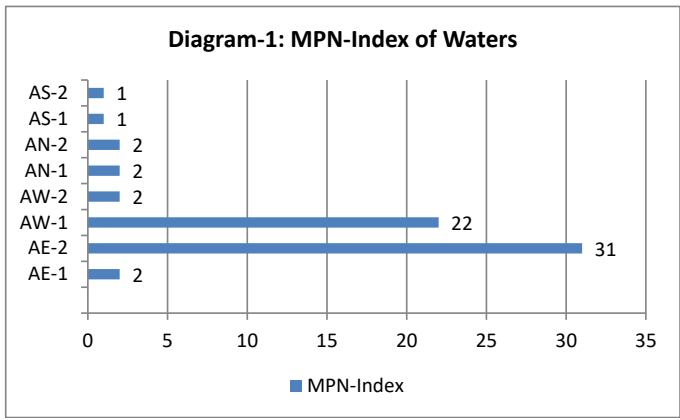

Fig. 3: MPN Index of waters.

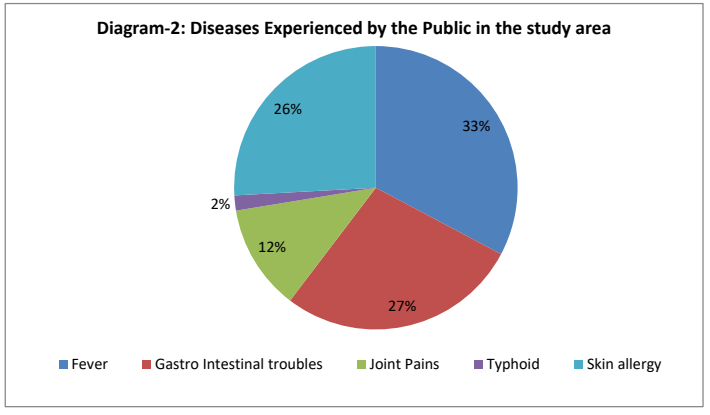

Fig. 4: Diseases experiences by the public in the study area. 
stop their growth at $\mathrm{pH} 5.0$ whereas some microorganisms can grow as low as 4.6-4.4 ( $\mathrm{pH} 4.6$ was considered to be the lower growth limit). The observed $\mathrm{pH}$ values of water samples are in the range of 6.93-8.92 in both seasons and are observed around $\mathrm{pH} 7$ which is favorable for the growth of microorganisms in the waters of the study area (Meter Group n.d.). Higher EC values indicate the presence of salt content in the waters and it is revealed by the higher values of TDS and salinity. TDS values crossed the permissible limit in all parameters. Total hardness values in all samples in the study area exceeded the permissible limit. TA values during the pre-monsoon season are within the permissible limit while it crossed the permissible limit during post-monsoon in all samples. Chloride and sulfate ion concentration values during pre- and post-monsoon seasons crossed the permissible limit during pre- and post-monsoon seasons. Phosphate ion concentration values range from $0.11-3.86 \mathrm{mg} . \mathrm{L}^{-1}$ and 0.14-4.73 mg. $\mathrm{L}^{-1}$ during pre- and post-monsoon seasons respectively. Nitrate ion concentration values during pre- and post-monsoon seasons are within the permissible limit in the majority of samples collected near the aquaculture activity area. Calcium and magnesium values in the waters exceeded the permissible limit in the majority of the samples. Na levels during pre-monsoon range from $238-3738 \mathrm{mg} . \mathrm{L}^{-1}$ and during post-monsoon range from $77.9-1962.2 \mathrm{mg} . \mathrm{L}^{-1}$. K levels range from 16.5-605.0 mg. $\mathrm{L}^{-1}$ during pre-monsoon season and it ranges from 6.4-293.9 mg. $\mathrm{L}^{-1}$ during post-monsoon which reveals higher levels of salt content present in the waters collected near aquaculture activity areas.

Irrigation parameters: Irrigation parametric values are presented in the Table 5 along with the BIS standard values which reveal percent sodium values during pre-monsoon season exceeded in major locations while during the postmonsoon season these values are within the permissible limit in the majority of the sample which reveals the unsuitability of these waters in terms of $\% \mathrm{Na}$ values for irrigation during the pre-monsoon season while these waters can be considered for irrigation in the majority of the sampling locations. SAR in most of the samples during pre- and post-monsoon seasons indicates the suitability for irrigation in terms of SAR values. RSC values during pre- and post-monsoon seasons in the study area are within the irrigation standards which confirm the suitability for irrigation. Kelly's ratio values during pre- and post-monsoon seasons exceeded the permissible limit for irrigation. Magnesium hazard values during premonsoon season in the majority of the samples are within the irrigation standards while in post-monsoon these values exceeded irrigation standard value.

Correlation analysis: During the pre-monsoon season, EC, TDS, salinity, chloride, TH, sodium, calcium, and magnesium values strongly correlated and influences the water quality in the study area (Table 6). While in the post-monsoon season, EC, salinity, TH, chloride, TH, sodium, magnesium, and nitrate correlated strongly and majorly affects the water quality (Table 6).

MPN count: The water sample AE-1 was found with an MPN count of 2 and water sample AE- 2 with MPN count 31 . Water sample AW-1 is observed with MPN count 22 while the water sample AW-2 is with MPN count 2. Water sample AN- 1 is found to contain MPN count 2 and the water sample AN-2 with MPN count 2. Water samples AS-1 and AS-2 are observed with MPN count 1 each. Except for the water samples AS-1 and AS-2, the remaining samples are observed with MPN count 2 and more than 2 which indicates microbial contamination of these water samples in the study area.

Bacterial species: The bacteria Pseudomonas generally tend to live and breed in water, soil, and damp areas. People with a weakened immune system are prone to severe infections like fever, skin rashes, joint pains, and ear infections. $C$. freundii is a species of facultative anaerobic gram-negative bacteria. Bacteria are often found in the water, soil, food, and intestines of humans and animals. The bacteria can cause several types of infections in bones, intestines, respiratory and urinary tracks. E. coli is a type of bacteria and normally exists in the intestines. Most types of $E$. coli are harmless and even help the digestive tract healthy. But some strains can cause diarrhea if contaminated water is consumed or by eating contaminated food. E. coli stains can also cause abdominal cramps, fever, and acute kidney failure.

The water sample AE-1 was found to have bacterial species Pseudomonas and the water sample AE-2 was found to have $C$. freundii. Water sample AW-1 was found to have $C$. freundii and the water sample AW-2 was found to have E. coli. Water sample AN-1 was found to have Pseudomonas while the water sample AN-2 was found to have E. coli. Water sample AS-1 was found to contain C. freundii while the water sample AS-2 was found to have $C$. Freundii. Due to the presence of pathogenic bacteria like Pseudomonas, $C$. freundii, and E. coli in the waters of the study area, health problems like fever, bone-related problems like joint pains, gastrointestinal troubles, and skin diseases can be caused.

Health survey: The health survey information (Table 8) revealed the details of the sufferings of people residing in the nearby areas of the aquacultural activity. People of different ages (from $1 \mathrm{yr}$ to $60 \mathrm{yrs}$ ) and the health problems viz., fever, gastrointestinal troubles, typhoid, and skin diseases experienced by them are correlated with the presence of the pathogenic species present in waters.

\section{CONCLUSION}

The parametric values of temperature and the $\mathrm{pH}$ of water 
samples are in favor of pathogenic bacterial growth in waters of the study areas indicating the microbial contamination of waters. Physicochemical parametric values of the majority of the parameters confirm the chemical contamination of waters and indicate their unsuitability for drinking purposes. Irrigation parameters like \% Na, SAR, Kelly's Ratio, and $\mathrm{MH}$ also reveals the unsuitability of these waters in the majority of the sampling locations. The study results revealed that health problems like fever, gastrointestinal troubles, bone-related health problems like joint pains, and skin diseases experienced by the people residing in the nearby areas of aquacultural areas are the actual contribution of pathogenic bacteria like Pseudomonas, C. freundii, and E. coli in waters. Disinfection and sterilization are to be done continuously every time to eliminate microbial contamination. Very sensitive and frequent monitoring of waters is suggested and a wide range of biosensor systems are to be developed for usage from time to time to assess the quality of waters to protect the health of the people if these waters are proposed for consumption or drinking.

\section{ACKNOWLEDGEMENT}

The authors express their sincere thanks and gratitude to the authorities of Pragati Engineering College (A), Surampalem, A. P India for their support in carrying out the analysis in R\&D laboratories. The authors also convey their thanks to the faculty, Department of Microbiology, Y.N.College (A), Narasapuram for their cooperation in microbial analysis.

\section{REFERENCES}

Alagarswamy, K. 1995. Report on a regional study and workshop on the environmental assessment and management of aquaculture development, FAO Corporate Document Repository,pp. 1-26.

APHA1992. The Standard Method for the Examination of Water and Wastewater (19th ed.). American Public Health Association, Washington.

Arnone, R.D. and Walling, J.P. 2007. Waterborne pathogens in urban watersheds. Water Health, 5(1): 149-162.

Boehm, A. and Sassoubre, L.M. 2014. Enterococci as Indicators of Environmental Contamination. In: Gilmore MS, Clewell DB, Ike Y. (eds.) Enterococci: From Commensals to Leading to Causes of DrugResistant Infections. Massachusetts Eye and Ear Infirmary, Boston, PMID: 24649503.

Dahdouh-Guebas, F., Collin, S., Lo Seen, D., Ronnback, P., Depommier, D., Ravishankar, T. and Koedam, N. 2006. Analysing ethnobotanical and fishery-related importance of mangroves of the East-Godavari Delta (Andhra Pradesh, India) for conservation and management purposes. J. Ethnobiol. Ethnomed., 2(24): 1-22.
Falconer, L., Telfer, T.C. and Ross, L.G. 2018, Modelling seasonal nutrient inputs from non-point sources across large catchments of importance to aquaculture. Aquaculture, 495: 682-692.

Ibrahim, A.B., Mohd Khan, A. and Norrakiah, A.S. 2014. Microbiological risk assessment of freshwater aquaculture fish: From farm to table. Adv. Environ. Biol., 8(14): 105-111.

Ikonen, J.M., Hokajärvi, A.M., Heikkinen, J., Pitkänen, T., Kolehmainen, M. and Pursiainen, A. 2017. Drinking water quality in distribution systems of surface and ground water works in Finland. J. Water Secur., 3: 1-10.

Joao, C., P.S. 2010. Water microbiology: Bacterial pathogens and water. Int. J. Environ. Res. Pub. Health, 7(10): 3657-370.

Madoux-Humery, A.S., Dorner, S., Sauve, S., Aboulfadl, K., Galarneau, M., Servais, P. and Prevost, M. 2016. The effects of combined sewer overflow on riverine sources of drinking water. Water Res. 92: 218-227.

Massoud, A., Jurdi, M. and Nuwayhid, I. 2010. The challenges of sustainable access to safe drinking water in rural areas of developing countries: Case of Zawtan Elcharkieh, Southern Lebanon. J. Environ. Health, 72(10): 24-30.

Mir, A.B.Q., Pandey, G.C. and Sarwar, S.G. 2004. Impact of SKIMS effluent on the water quality of Anchar lake, Kashmir. Indian J. Environ. Ecoplan., 8(2): 389-394.

Nagaraju, D and Papanna, C. 2009. Hydrogeochemical Studies of Kabini River Basin, Karnataka, India. Nat. Environ. Pollut. Technol., 8(1): 111-118.

NEERI 1995. Investigation report on impacts of aquaculture farming and remedial measures in ecologically fragile coastal areas in the states of Andhra Pradesh and Tamilnadu. Submitted to Hon'ble Supreme Court, National Environmental Engineering Research Institute, Nagpur, India, p. 143.

Obiri-Danso, K. and Jones, K. 1999. Distribution and seasonality of microbial indicators and thermophilic campylobacters in two freshwater bathing sites on the River Lune in northwest England. J. Appl. Microbiol., 87: 822-832.

Obiri-Danso, K. and Jones K. 1999. The effect of a new sewage treatment plant on fecal indicator numbers, campylobacters, and bathing water compliance in Morecambe Bay. J. Appl. Microbiol., 86: 603-614.

Ramesh, R.P., Gkigbo, R.N., Madhusoodan, S.A. and Radha, L. 2008. Groundwater pollution due to aquaculture in the east coast region of Nellore district, Andhra Pradesh, India. Afr. J. Environ. Sci. Technol. 2(3): 40-50

Ramteke, D.S. and Moghe, C. A. 1988. Manual on Water and Wastewater Analysis. National Environmental Engineering Research Institute, Nagpur, India.

Raveen, R., Chennakrishnan, C. and Stephen, A. 2008. Impact of pollution on the quality of water in three freshwater lakes of sub-urban Chennai. Nat. Environ. Pollut. Technol., 7(1): 61-64.

Sohan, S. and Iqbal, S. 2012. Microbiological analysis of surface water in Indore, India. Res. J. Recent Sci., 1(ISC-2011): 323-325.

World Health Organization (WHO). 2010. Unsafe water, sanitation, and hygiene, 2010. http://www.who.int/publications/cra/chapters/ volume2/1321-1352.pdf

World Health Organization (WHO). 2014. Water Quality and health. Drinking water chlorination - A review of disinfection practices and issues. http:// www.waterandhealth.org/drinkingwater/wp.html. Accessed 28 Apr 2014.

Meter Group n.d. How water activity and $\mathrm{pH}$ work together to control microbial growth. https://www.metergroup.com/food/articles/howwater-activity-and-ph-work-together-to-control-microbial-growth. 